DOI: https://doi.org/10.31933/jemsi.v3i3

Received: 8 November 2021, Revised: 15 Desember 2021, Publish: 1 Januari 2022

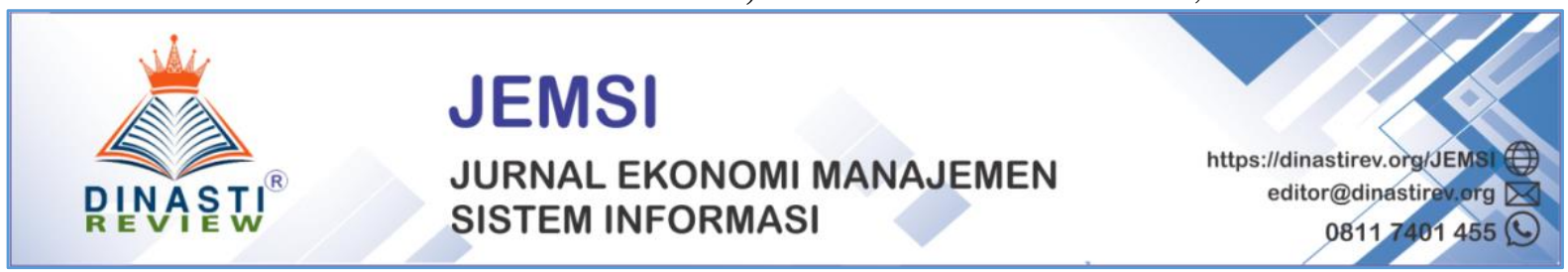

\title{
FAKTOR-FAKTOR YANG MEMPENGARUHI INFRASTRUKTUR TEKNOLOGI INFORMASI : KEUANGAN, FLEKSIBILITAS TI, KINERJA ORGANISASI
}

\author{
Vinda Putri ${ }^{1}$ \\ Mahasiswa Universitas Bhayangkara Jakarta Raya (UBJ) email: vinda101097@gmai.com
}

Korespondensi Penulis: Vinda Putri

\begin{abstract}
Abstrak: Saat ini dunia sudah semakin maju, khususnya dibidang teknologi informasi. beberapa negara yang sudah maju maupun negara yang masih berkembang, sudah sangat mengenal berbagai macam jenis teknologi informasi. Di era digital sekarang ini teknologi informasi sudah sangat maju, hal tersebut dapat dirasakan dan dilihat dari perubahan sumber daya alam menjadi berbagai macam alatnya. Seiring perkembangannya, teknologi informasi bermunculan sangat nyata seperti yang kita gunakan sehari-hari hp, komputer, laptop, mesinmesin, motor, mobil, dan masih banyak lagi lainnya. Pesatnya perkembangan berbagai macam teknologi informasi semakin meluas keseluruh daerah-daerah yang berada disuatu negara. Sehingga menjadikan daerah satu dengan daerah yang lain terhubung dalam suatu sistem. guna mendapatkan berbagai jenis informasi yang ingin diketahui oleh suatu daerah tersebut. Semua terhubung dalam suatu sistem yang dinamakan sistem informasi manajemen (SIM). Rumusan Masalah dari penelitian ini adalah apa saja faktor yang mempengaruhi infrastruktur teknologi informasi dan bagaimana penerapan infrastruktur teknologi informasi terhadap suatu organisasi. Tujuan dari penelitian ini adalah untuk mengetahui faktor yang mempengaruhi infrastruktur teknologi informasi dan penerapan teknologi informasi terhadap kinerjadari suatu organisasi.
\end{abstract}

Kata Kunci: sistem informasi manajemen,penerapan sistem informasi manajemen, Infrastruktur Teknologi Informasi: Keuangan, Fleksibilitas Teknologi informasi, dan Kinerja Organisasi.

\section{PENDAHULUAN \\ Latar Belakang}

Teknologi informasi merupakan sebuah perkembangan teknologi komputer dengan telekomunikasi. Definisi informasi itu sendiri adalah suatu hasilpengolahan berupa data yang memiliki nilai bermanfaat bagi sekitanya.untuk menghasilkan data yang memiliki value, maka diperlukan perlatan untuk pengolahan data,seperti komputer.komputer merupakan bentuk dari teknologin informasi yang dapat melakukan prose pengolahan data.menjadi suatu informasi.

Menurut (Halim, 2015) Infrastruktur Teknologi Informasi adalah suatu asset jangka Panjang yang bias disebut sebagai nilai untuk menghasilkan value dari suatu organisasi. Pengelolaan sistem yang baik bisa dilakukan apabila sesuai standar yang berlaku dalam suatu 
organisasi. Dalam pengelolaan sering kali adanya masalah, terutama masalah dalam pendanaan, maka dari itu pendanaan merupakan faktor yang sangat mempengaruhi kelangsungan Infrastruktur Teknologi informasi.jik pendanaan dapat di kelola dengan baik dari suatu organisasi, maka infrastruktur Teknologi informasi bisa berkembang dengan efektif dan efisien. perkembangan infrastruktur Teknologi informasi membutuhkan pendanaan sedemikian rupa untuk memudahkan semua jenis pekerjaan sehingga pekerjaan menjadi lebih efektif.(Ali H. d., 2010).

Perkembangan Infrastruktur Teknologi informasi sangat mempengaruhi perubahan teknologi dalam organisasi dengan cara fleksibilitas Teknologi informasi. Fleksibilitas dari infrastruktur Teknologi informasi sangat penting dalam organisasi untuk meminimalisir risiko yang akan terjadi (Isdianto, 2014). Sedangkan Infrastruktur Teknologi informasi ini dapat diterapkan dengan menggunakan rencana strategis dari suatu teknologi informasi yang disesuaikan dengan rencana dari organisasi. Maka dari itu, suatu perusahaan harus meningkatkan kinerjaang maksimal dalam organisasinya supaya dapat memanfaatkan Infrastruktur Teknologi informasi dengan baik. Berdasarkan pengalaman empirik, banyak mahasiswa dan dosen muda juga peneliti lainnya, kesulitan untuk mencari artikel pendukung dalam riset sebagai penelitian terdahulu atau sebagai penelitian yang relevan. Artikel sebagai peneliti yang relevan di perlukan untuk memperkuat teori yang di teliti dan untuk melihat hubungan antar variable dan membangun hipotesis.

\section{Rumusan Masalah}

Berdasarkan latar belakang yang telah dipaparkan, maka rumusan masalah pada artikel ini adalah :

1) Pengaruh atau Hubungan Keuangan terhadap Infrastruktur TI

2) Pengaruh atau Hubungan Fleksibilitas TI terhadap Infrastruktur TI

3) Pengaruh atau Hubungan Kinerja Organisasi terhadap Infrastruktur TI

\section{Tujuan Penelitian}

Adapun tujuan penulisan artikel ini adalah :

1) untuk mengetahui pengaruh hubungan keuangan terhadap infrastruktur TI

2) untuk mengetahui pengaruh fleksibilitas TI terhadap infrastruktur TI

3) untuk mengetahui pengaruh kinerja organisasi terhadapinfrastruktur TI

\section{KAJIAN TEORI}

\section{Definisi Sistem Informasi Manajemen (SIM)}

Menurut Mc.Leod dalam Yakub (2012) dalam (Vindi Agustiandra, 2019) mendefinisikan SIM (Sistem Informasi Manajemen) sebagai suatu sistem yang menyediakan informasi bagi para pemakainya dengan berbasis komputer. Sedangkan Menurut Moeljodihardjo dalam Sutabri (2005) dalam (Vindi Agustiandra, 2019) SIM adalah sebuah metode yang digunakan untuk menghasilkan informasi yang tepat dan berguna dalam manajemen diluar organisasi serta dapat menunjang dalam proses pengambilan keputusan, perencaan, dan juga dalam proses pengawasan. Selain itu Hartono (2013) dalam (Vindi 
Agustiandra, 2019) mengungkapkan bahwa SIM adalah sebuah sistem, yang terdiri dari rangkaian dan komponen-komponen yang saling bekerjasama untuk menghasilkan sebuah informasi yang berguna bagi manajemen disebuah perusahaan.

Sistem informasi adalah sebuah sistem yang terdiri dari berbagai jenis komponen, elemen-elemen yang saling bekerjasama demi suatu tujuan yaitu menghasilkam sebuah informasi yang berguna membantu pekerjaan dari manajemen perusahaan ataupun organisasi. penerapan sistem informasi di dalam sebuah organisasi untuk mempermudah divisi- divisi dalamsuatu organisasi, sehingga mendapatkan informasi yang dibutuhkan (Lipursari, 2013). Selain itu ada beberepa manfaat dalam penerapan Sistem Informasi Manajemen (SIM) yaitu dapat meningkatkan efisiensi dan efektivitas data secara akurat dan tepat waktu, mempermudah pekerjaan manajemen mulai dari perencanaan, pelaksanaan, pengawasan dan lainnya, mampu meningkatkan kualitas sumber daya manusia, dan dapat meningkatkan produktivitas serta penghematan biaya dalam organisasi.

Sistem informasi manajemen merupakan media dalam mengelola hasil (output) dengan memperhatikan masukan (input) untuk mencapai tujuan yang diharapkan baik dalam suatu organisasi. semua hasil (output) akan terangkum dalam sistem informasi manajemen berupa data. Data yang didapat harus berdasarkan keadaan yang sebenarnya, valid, padat, jelas dan dapat dipertanggungjawabkan keabsahannya. pengumpulan, penyimpanan dan pengolahan data dapat menggunakan perangkat lunak yang dapat memudahkan dalam menciptakan, mendefinisikan, maupun menyimpan data dalam jangka waktu lama dan dapat dilaksanakan secara efektif daneffisien terangkum dalam suatu sistem informasi. dengan adanya sistem informasi, negara, daerah, ataupun organisasi yang berada didalamnya menjadi semakin efektif dalam manajemen data sehingga data yang didapat berupa informasi yang tepat guna, tepat waktu dan relevan. Untuk mendapatkan, menambah, mendistribusikan suatu informasi dengan tujuan meningkatkan pengambilan keputusan, meningkatkan kinerja dari suatu organisasi untuk mencapai tujuan utama dari suatu organisasi semua terhubung dalam sistem informasi manajemen.

Salah satu aset organisasi yang paling berharga saat ini adalah sistem informasi yang responsif dan berorientasi pada pengguna. Dengan sistem yang baik diharapkan dapat meningkatkan produktifitas, menurunkan jumlah persediaan yang harus dikelola, mengurangi kegiatan yang tidak memberikan nilai tambah, meningkatkan pelayanan kepada pelanggan dan mempermudah pengambilan keputusan bagi manajemen untuk mengkoordinasikan kegiatan dalam organisasi. Oleh karena itu, audit atas pengembangan dan pemeliharaan sistem informasi semakin dibutuhkan, sehingga sistem yang dimiliki efektif dalam menyelesaikan pekerjaan dan meningkatkan efisiensi kerja. Efektivitas kerja dimaksud merupakan penyelesaian pekerjaan yang tepat waktu yang disertai dengan kualitas dan kuantitas serta mutu yang dihasilkan sesuai dengan target yang telah ditentukan. Ya'kub (1984: 39) mengemukakan bahwa: "Efektivitas kerja adalah suatu keadaan yang menunjukkan tingkat keberhasilan kegiatan manajemen dalam mencapai tujuan yang telah ditetapkan terlebih dahulu". Pendapat tersebut menjelaskan efektivitas kerja dari sudut pandang kegiatan manajemen yang bertujuan untuk mencapai 
tujuan organisasi. Pelaksanaan suatu pekerjaan dinilai memenuhi standar yang baku bila mengacu pada hasil pekerjaan yang telah ditetapkan, sehingga mencapai hasil dan sasaran yang telah ditetapkan dan dicapai secara maksimal termasuk pada Bidang Sumber Daya Kesehatan Dinas Kesehatan Provinsi Jawa Barat.

\section{Infrastruktur Teknologi Informasi (Y)}

Kegiatan masyarakat yang menekankan inefisiensi dari aktivitas organisasinya dengan struktur yang digunakan untuk menopang hal tersebut dengan berwujud fisik disebut juga infrstruktur (Sekarsari, 2019). Dalam organisasi Teknologi Informasi merupakan salah satu sumberdaya yang penting untuk unggul dalam persaingannya di era globalisasi saat ini (Ali, 2009). Infrastruktur Teknologi Informasi menurut (Laudon, 2010) adalah investasi pada perangkat keras, lunak, dan layanan-layanan seperti konsultasi, Pendidikan, dan pelatihan yang dibagi ke seluruh perusahaan atau seluruh unit bisnis di perusahaan. Pada bidang IT yang mencakup perangkat keras seperti computer mainframe, server, laptop, dan PDA, sedangkan perangkat lunak seperti system operasi dan aplikasi yang memiliki banyak fungsi, selain itu juga ada database untuk menyimpan data penting (Reynolds, 2010).

\section{Keuangan (X1)}

Menurut (Sundjaja, 2003) Keuangan adalah ilmu sekaligus seni pengelolaan uang yang berpengaruh pada kehidupan individu maupun organisasi. Sehingga keuangan disetiap perusahaan mempunyai peran penting untuk keberlangsungan dalam berbisnisnya. Mengelola keuangan dengan baik akan mendapatkan dana dan memanfaatkan segala urusan dengan efektif (Maisharoh, 2020).

\section{Fleksibilitas Teknologi Informasi (X2)}

Fleksibilitas adalah kemampuan organisasi dalam menyikapi perubahan lingkungan, baik internal maupun eksternal (Arafat, 2016). Perubahan lingkungan ini dapat dimanfaatkan untuk peluang-peluang baru baik dalam organisasi kecil maupun besar sehinga dapat mengatasi ukuran organisasi tersebut (Gaol, 2008).

Menurut (Byrd, 2000) Flesksibilitas Teknologi Informasi ialah kemampuan Infrastruktur TI untuk dengan mudah menyebarkan berbagai variasi perangkat keras, lunak, teknologi komunikasi, data dan sebagainya untuk berkomitmen dengan komponen teknikal fisikal maupun personal. (Tjahyawati A., 2012) berpendapat bahwa fleksibilitas teknologi informasi sangat pening untuk mendukung proses kinerja karyawan terhadap Infrastruktur. Inovasi yang ada pada teknologi informasi membuat karyawan menjadi berkembang dalam menghadapi perubahan-perubahan teknologi informasi. (Laudon, 2010) menyatakan kalau fleksibilitas, efisiensi, dan kehandalan merupakan transformasi IT yang mencakup pada penggunaan layanannya.

\section{Kinerja Organisasi (X3)}


(Aima, 2017) berpendapat kinerja adalah hasil yang dicapai karena termotivasi oleh pekerjaan dan puas dengan pekerjaan yang mereka lakukan. Sedangkan (Anshori, 2015) menyatakan kinerja merupakan refleksi atas pencapaian kuantitas dan kualitas pekerjaan yang dihasilkan individu, kelompok, dan organisasi yang dapat diukur. Hasilnya dapat diukur dengan memberikan umpan balik berdasarkan standar ukuran kualitas dan mutu pada kinerja organisasi tersebut (Kumaat, 2015). Meningkat kinerja dilakukan dalam sebuah organisasi yang bertujuan agar targetnya bisa tercapai oleh organisasi tersebut. Pengertian Kinerja Organisasi sendiri adalah hasil akumulatif dari seluruh aktivitas kerja di dalam perusahaan (Robbins, 2010). (Widuri, 2013) menyatakan kinerja organisasi merupakan pengaruh terhadap teknologi informasi. Menurut (Sobandi, 2006) kinerja organisasi merupakan sesuatu yang telah dicapai oleh organisasi dalam kurun waktu tertentu, baik yang terkait dengan input, output, outcome, benefit, maupun impact. Tentunya hasil kerja yang dicapai oleh kinerja organisasi ini penuh tanggung jawab akan tercapainya peningkatan kinerja yang efektif dan efisien. Jadi dapat disimpulkan dalam memenuhi kebutuhan pelanggan sehari-hari oleh suatu organisasi, kinerja organisasi sangatlah berpengaruh dalam hal ini agar lebih baik

\section{Perkembangan Sistem Informasi Manajemen}

\section{Menurut 80. Slamet Haryanto.sistem informasi manajemen.}

Pada awal perkembangan komputerisasi informasi, komputer belum mempunyai program yang berjalan secara otomatis, melainkan hanya menjalankan komando yang dimasukkan secara manual ke dalam komputer. Setelah tahun 2000'an, sistem informasi manajemen mulai berkembang sebagai satu sistem yang terintegrasi pada berbagai induk perusahaan dan cabang-cabangnya. Sistem tersebut kemudian dibentuk dalam sistem informasi berbasis komputer (Computer Based Information System). Hingga kini, sistem informasi berjalan secara terintegrasi dan berjalan secara otomatis. SIM sendiri mempunyai elemenelemen fisik yang dibutuhkan untuk kelancaran sistem yang digunakan, yaitu perangkat keras komputer, perangkat lunak, yaitu perangkat lunak sistem umum, perangkat lunak terapan umum, serta program aplikasi. Selanjutnya, dalam SIM terdapat database dan prosedur pelaksanaan sistem manajemen perusahaan dan tentunya, petugas yang mengoperasikan semua sistem tersebut.

Bidang Sumber Daya Kesehatan Dinas Kesehatan Provinsi Jawa Barat adalah salah satu unit kesatuan kerja di dalam struktur organisasi Dinas Kesehatan Provinsi Jawa Barat menurut Peraturan Gubernur Jawa Barat Nomor 32 Tahun 2009, tugas pokok Bidang Sumber Daya Kesehatan Dinas Kesehatan Provinsi Jawa Barat yaitu menyelenggarakan pengkajian bahan kebijakan teknis sumber daya kesehatan. Penciptaan efektivitas kerja pegawai merupakan salah satu upaya merealisasikan tugas pokok tersebut. Tetapi efektivitas kerja pegawai dapat tercapai, bila seluruh unit kerja organisasi dapat bekerja dan saling mendukung satu dengan yang lainnya. Bidang Sumber Daya Kesehatan Dinas Kesehatan Provinsi Jawa Barat dalam melaksanakan tugas pokok, fungsi, rincian tugas unit dan tata kerjanya mengalami berbagai hambatan dalam pelaksanaannya, mengingat keterbatasan kemampuan pegawai dan terbatasnya fasilitas yang dimiliki, sehingga hasil kerja tidak berjalan secara penuh. Hambatan- 
hambatan tersebut berpengaruh terhadap hasil kerja organisasi secara keseluruhan yang menyebabkan efektivitas kerja pegawai tidak berjalan sesuai target dan sasaran.

\section{Konsep Dasar Informasi Ada beberapa konsep dasar informasi, antara lain sebagai berikut.}

1. Data yang diolah menjadi suatu bentuk yang lebih berguna serta lebih berarti bagi yang menerimanya. DBMS adalah singkatan dari Database Management System yang mana merupakan sebuah sistem yang digunakan dalam proses pengelolaan data yang ada pada database dengan metode komputerisasi. DBMS merupakan sebuah perangkat lunak yang berfungsi untuk mengelola kumpulan data yang tersimpan dalam suatu database dengan cara memanggil query (kueri) atas basis data tersebut. DBMS dapat membantu dalam pengolahan kumpulan data dalam jumlah besar. DBMS juga dapat melakukan pengolahan data dengan mendefinisikan, membuat, dan menyediakan akses kontrol terhadap data-data tersebut. Sistem DBMS ini pada dasarnya terdiri dari berbagai perintah yang terekam menggunakan sistem komputer untuk digunakan sebagai media proses penyimpanan dan pengolahan data operasional pada suatu organisasi, sehingga data-data tersebut dapat menjadi informasi yang optimal guna keperluan dalam pertimbangan pengambilan keputusan.

2. Sesuatu yang nyata atau bisa juga setengah nyata yang bisa mengurangi derajat ketidak pastian mengenai suatu keadaan atau kejadian.

\section{Tujuan Sistem Informasi Manajemen}

Berikut ini merupakan tujuan dari sistem informasi manajemen.

1. Menyediakan suatu informasi untuk pengambilan suatu keputusan.

2. Menyediakan suatu informasi yang dipergunakan didalam suatu perencanaan, pengendalian, pengevaluasian dan juga perbaikan berkelanjutan.

3. Menyediakan suatu informasi yang dipergunakan di dalam suatu perhitungan harga pokok produk, jasa dan tujuan lainnya yang diinginkan oleh manajemen.

\section{Tahapan proses manajemen}

Proses manajemen bisa diartikan sebagai aktivitas-aktivitas atau kegiatan-kegiatan antara lain sebagai berikut.

1. Perencanaan, yaitu untuk bisa mencapai suatu tujuan akhir yang merupakan suatu aktivitas manajemen yang disebut dengan perencanaan. Oleh karena itu, perencanaan memberikan syarat suatu penetapan tujuan dan juga identifikasi metode untuk bisa mencapai tujuan tersebut.

2. Pengendalian, Jika suatu rencana sudah dibuat, rencana itu harus diimplementasikan. Kemudian manajer dan pekerja harus memonitor pelaksanaannya untuk bisa memastikan rencana itu berjalan dengan baik.

3. Pengambilan Keputusan, adalah proses memilih suatu keputusan di antara berbagai alternatif. Fungsi dari manajerial ini adalah suatu jalinan antara perencanaan dan pengendalian. Manajer tersebut harus memiliki visi, skill serta metode untuk melaksanakan tujuan yang telah dipilih. 


\section{Manfaat sistem informasi manajemen}

Manfaat Sistem Informasi Manajemen Ada beberapa manfaat sistem informasi manajemen. Antara lain sebagai berikut.

1. menjadi suatu wadah untuk memuat suatu informasi sebanyak banyaknya dan bisa dipertanggungjawabkan absahannya..

2. Meningkatkan aksesbilitas data yang ada secara akurat dan tepat waktu bagi para pemakai, tanpa mengharuskan adanya perantara sistem informasi.

3. Mengidentifikasi kebutuhan- kebutuhan akan keterampilan pendukung sistem informasi.

4. Mengembangkan proses perencanaan yang efektif

\section{Penerapan Sistem Informasi Manajemen}

Beberapa contoh nyata dalam penerapan sistem informasi manajemen adalah sebagai berikut:

1. Enterprise Resource Planning (ERP) Sistem ERP ini biasanya digunakan oleh sejumlah perusahaan besar dalam mengelola manajemen dan melakukan pengawasan yang saling terintegrasi terhadap unit bidang kerja Keuangan, Accounting, Sumber Daya Manusia, Pemasaran, Operasional, dan Pengelolaan Persediaan.

2. Supply Chain Management (SCM) Sistem SCM ini sangaat bermanfaat bagi pihak manajemen dimana data data yang disajikan terintegrasi mengenai manajemen suplai bahan baku, mulai dari pemasok, produsen, pengecer hingga konsumen akhir.

3. Transaction Processing System (TPS) TPS ini berguna untuk proses data dalam jumlah yang besar dengan transaksi bisnis yang rutin. Program ini biasa diaplikasikan untuk manajemen gaji dan inventaris. Contohnya adalah aplikasi yang digunakan untuk Bantuan Keuangan Desa Pemprov Jawa Timur.

4. Office Automation System (OAS) Sistem aplikasi ini berguna untuk melancarkan komunikasi antar departemen dalam suatu perusahaan dengan cara mengintegrasikan server-server komputer pada setiap user di perusahaan. Contohnya adalah email.

5. Knowledge Work System (KWS) Sistem informasi KWS ini mengintegrasikan satu pengetahuan baru ke dalam organisasi. Dengan ini, diharapkan para tenaga ahli dapat menerapkannya dalam pekerjaan mereka.

6. Informatic Management System (IMS) IMS berfungsi untuk mendukung spektrum tugas-tugas dalam organisasi, yang juga dapat digunakan untuk membantu menganalisa pembuatan keputusan. Sistem ini juga dapat menyatukan beberapa fungsi informasi dengan program komputerisasi, seperti e- procurement.

7. Decision Support System (DSS) Sistem ini membantu para manajer dalam mengambil keputusan dengan cara mengamati lingkungan dalam perusahaan. Contohnya, Link Elektronik di sekolah Tunas Bangsa, yang mengamati jumlah pendapatan atau pendaftaran siswa baru setiap tahun.

8. Expert System (ES) dan Artificial Intelligent (A.I.) Sistem ini pada dasarnya menggunakan kecerdasan buatan untuk menganalisa pemecahan masalah dengan 
menggunakan pengetahuan tenaga ahli yang telah diprogram ke dalamnya. Contohnya, sistem jadwal mekanik.

9. Group Decision Support System (GDSS) dan Computer-Support Collaborative Work System (CSCWS) Serupa dengan DSS, tetapi GDSS mencari solusi lewat pengumpulan pengetahuan dalam satu kelompok, bukan per individu. Biasanya berbentuk kuesioner, konsultasi, dan skenario. Contohnya adalah e-government.

10. Executive Support System (ESS) Sistem ini membantu manajer dalam berinteraksi dengan lingkungan perusahaan dengan berpegang pada grafik dan pendukung komunikasi lainnya.

\section{METODE PENELITIAN}

Metode penulisan artikel ilmiah ini menggunakan metode kualitatif.Penelitian kualitatif dengan analisis deskriptif berupa gambaran penjelasan mengenai sistem informasi dan perkembangan teknologi informasi serta melihat penerapan sistem teknologi informasi pada suatu organisasi apakah berjalan dengan efektif dalam suatu organisasi atau tidak berjalan dengan efektif.

\section{HASIL DAN PEMBAHASAN}

Hubungan atau Pengaruh antara variable exogen terhadap variable endogen Artikel ini menganalisis dan membahas tentang variable-variabel Infrastruktur Teknologi Informasi yaitu Keuangan, Fleksibilitas TI, dan Kinerja Organisasi

1. Pengaruh / hubungan Keuangan (X1) terhadap Infrastruktur Teknologi Informasi(Y) Keuangan berpengaruh terhadap Infrastruktur Teknologi Informasi, pernyataan ini berdasarkan artikel-artikel dari riset yang relevan dan di review, diantaranya adalah: I(Noviari, 2007), (Forda, 2013), (Fitriawati, 2017), dan (Widajanti, 2011) Pendanaan/keuangan disetiap organisasi pasti mempunyai pendapatan per kapita yang tinggi, sehingga penggunaan internet juga akan tinggi. Hal ini diwujudkan dengan adanya inovasi baru terhadap Infrastruktur TI. Dengan infrastruktur Teknologi Informasi yang bagus, maka perusahaan juga mampu untuk bersaing dengan kompetitornya. Keuangan dalam Infrastruktur Teknologi Informasi disebut juga pendanaan. Keuangan adalah mempelajari bagaimana suatu individua tau organisasi untuk mengalokasikan dana dan menghitung risiko dalam menjalankan suatu proyek (Rachmat, 2020). Dengan demikian, keuangan berarti merupakan pendanaan dalam suatu pembangunan yang ada pada suatu organisasi tertentu. Penyelenggaraan keuangan yang dialokasikan untuk membantu dalam perubahan Infrastruktur Teknologi Informasi di suatu perusahaan. Pendanaan ini biasanya dikelola dengan Tata Kelola Infrastruktur Teknologi Informasi, sebab hal ini digunakan untuk menghindari risiko kekurangan dana saat melakukan perubahan. Berdasarkan uraian di atas, keuangan berpengaruh terhadap Infrastruktur Teknologi Informasi karena saat suatu organisasi ingin mengembangkan Infrastruktur TI pasti membutuhkan dana. Semakin baik pengelolaan keuangannya, maka semakin baik juga perubahan infrastruktur TI organisasi.

2. Pengaruh / hubungan fleksibilitas TI (X2) terhadap Infrastruktur Teknologi Informasi (Y) Fleksibilitas berpengaruh terhadap Infrastruktur Teknologi Informasi, pernyataan ini 
berdasarkan artikel-artikel dari riset yang relevan dan di review, diantaranya adalah: (Kartika, 2015), (Tjahyawati A., 2012), dan (Suryani, 2013). Fleksibilitas memberikan kemampuan untuk mengontrol lingkungan di luar organisasi secara efektif yang merupakan sumber potensial untuk mencapai posisi persaingan yang baik. Sedangkan menurut (Akintoye, 2012) infrastruktur ini lebih dirujuk ke asset Teknologi Informasi secara keras/fisik dan perangkat lunak yang menyediakan fondasi teknologi bagi organisasi aplikasi bisnis dimasa kini dan masa depan. Fleksibilitas infrastruktur teknologi ini memiliki komptensi yang diperlukan oleh pemilik suatu organisasi dalam memperoleh kinerja yang baik. Fleksibilitas infrastruktur juga mementukan kemampuan perusahaan untuk cepat dalam menanggapi perubahanperubahan dari luar, dimana hal ini sangat penting untuk membangkitkan inovasinya. Karena Infrastruktur sifatnya fleksibel, infrastruktur juga menjadi pondasi kekuatan akan menentukan system aplikasi yang akan dibangun oleh suatu organisasi. Berdasarkan uraian di atas dapat disimpulkan bahwa Fleksibilitas TI berpengaruh terhadap inovasi-inovasi baru Infrastruktur TI, sehingga Fleksibilitas ini perlu dievaluasi dan ditingkatkan lagi dalam pengembangan Infrastruktur TI.

3. Pengaruh / hubungan Kinerja Organisasi (X3) terhadap Infrastuktur Teknologi Informasi (Y) Kinerja Organisasi berpengaruh terhadap Infrastruktur Teknologi Informasi, pernyataan ini berdasarkan artikel-artikel dari riset yang relevan dan di review, diantaranya adalah: (Anggraini, 2013), (Iranto, 2012), (Djatikusumo, 2016), dan (Rahayu , 2020). Salah satu penyebab hasil Infrastuktur TI tidak konsisten adalah adanya perbedaan alat ukur yang digunakan dalam mengukur kinerja organisasi. Tetapi Infrastruktur Teknologi'Informasi menjadi sumber bisnis utama dan sumber kunci untuk keunggulan dalam bersaing setiap organisasi (Iranto, 2012). Ketersediaan infrastruktur teknologi informasi dalam lingkungan organisasi akan memiliki keunggulan dalam meningkatkan penyediaan informasi terhadap proses pengambilan keputusan manajemen untuk kinerja organisasi

Conceptual Framework Berdasarkan Kajian teori dan Review Artikel ilmiah, maka conceptual framework literature review ini adalah:

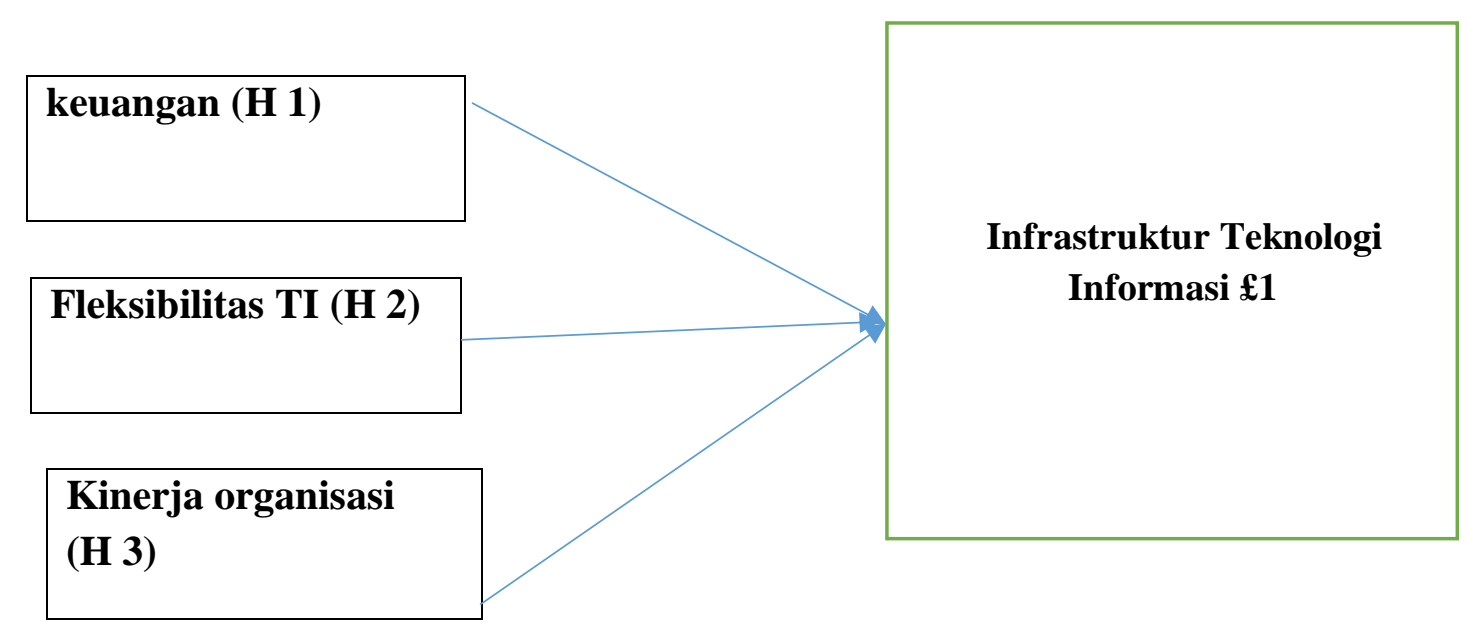

Gambar 1: Conceptual Framework 
Berdasrakan Kajian teori, hasil riset dari jurnal yang relevan dan juga berdasarkan kerangka konsep yang ada, maka dapat di rumuskan hipotesis untuk riset selanjutnya yang mungkin bisa dikembangkan yaitu:

1) Keuangan berpengaruh terhadap Infrastruktur Teknologi Informasi

2) Fleksibilitas Teknologi Informasi berpengaruh terhadap Infrastruktur Teknologi Informasi

3) Kinerja Organisasi berpengaruh terhadap Infrastuktur Teknologi Informasi

\section{KESIMPULAN DAN SARAN}

\section{Kesimpulan}

Berdasarkan artikel yang dianalisis pada kali ini, ada faktor-faktor yang mempengaruhi Infrastruktur Teknologi Informasi seperti yang diambil pada pembahasan diatas yaitu Keuangan, Fleksibilitas Teknologi Informasi, dan Kinerja Organisasi. sehingga dapat disimpulkan bahwa untuk membangun suatu hipotesis guna untuk melakukan riset selanjutnya bisa dilakukan seperti di bawah ini:

1. Pengaruh atau Hubungan Keuangan terhadap Infrastruktur TI

2. Pengaruh atau Hubungan Fleksibilitas TI terhadap Infrastruktur TI

3. Pengaruh atau Hubungan Kinerja Organisasi terhadap Infrastru

\section{Saran}

Berdasarkan kesimpulan di atas, maka saran pada artikel ini adalah bahwa masih banyak faKtor lain yang mempengaruhi Infrastruktur Teknologi Informasi, oleh karena itu masih di perlukan kajian yang lebih lanjut untuk melengkapi faKtor-faKtor lain apa sajakan yang dapat mempengaruhi Infrastruktur Teknologi Informasi.

\section{DAFTAR RUJUKAN}

Al-Rasjid, Harun. 1994. Analisis Jalur (Path Analysis) Sebagai Sarana

Statistika Dalam Analisis Kausal. Bandung: LP3ES Fakultas Ekonomi UNPAD.

Atmosudirdjo, Prajudi. 1982. Administrasi dan Manajemen. Jakarta: Ghalia Indonesia.

Damayanti, K., Fardinal., (2019). The Effect of Information Technology Utilization,

Management Support, Internal Control, and User Competence on Accounting Information System Quality. Schollars Bulletin, 5(12), 751-758.

Davis, George B. 1995. Kerangka Dasar Sistem Informasi Manajemen Bag 1.

Terjemahan: Hamalik. Jakarta: PT. Pustaka Binaman Pressindo

Effendi, Onong Uchjana. 1989. Sistem Informasi Manajemen. Bandung: Sinar Baru.

Fuad, Anis. 2006. Sistem Informasi Kesehatan Kabupaten/Kota (Sistem Informasi Manajemen Kesehatan). Yogyakarta: UGM.

Gibson, James L., John M. Ivancevich dan James H. Donnelly Jr., 1994.

Organizations Behavior: Behavior, Structure, Process. Terjemahan:

Nunuk Adriani. Jakarta: Binarupa Aksara. 
Hanifah, S., Sarpingah, S., \& Putra, Y. M., (2020). The Effect of Level of Education, Accounting Knowledge, and Utilization Of Information Technology Toward Quality The Quality of MSME' s Financial Reports. (3). https://doi.org/10.4108/eai.3-22020.163573

Herliansyah, Y., Nugroho, L., Ardilla, D., \& Putra, Y. M., (2020). The Determinants of Micro, Small and Medium Entrepreneur (MSME) Become Customer of Islamic Banks (Religion, Religiosity, and Location of Islamic Banks). The 1st Annual Conference Economics, Business, and Social Sciences, (2). https://doi.org/10.4108/eai.26-32019.2290775

Putra, Y. M. (2018). Sistem Manajemen Basis Data. Modul Kuliah Sistem Informasi Manajemen. FEB-Universitas Mercu Buana: Jakarta

Putra, Y. M., (2019). Analysis of Factors Affecting the Interests of SMEs Using Accounting Applications. Journal of Economics and Business, 2 (3), 818- 826. https://doi.org/10.31014/aior.1992.02.03.129 